\title{
MAOB Gene
}

National Cancer Institute

\section{Source}

National Cancer Institute. MAOB Gene. NCI Thesaurus. Code C125502.

This gene is involved in the oxidation of amines. 